\title{
Petrography and Mineralogy of the Quartz and Quartz-Feldspar Sulphide Veins in the Pan-African Syenitic Massif of Guider (North Cameroon)
}

\author{
Marguerite Boyabe1, Daouda Dawai ${ }^{*}$, Rigobert Tchameni ${ }^{2}$, Periclex Martial Fosso Tchunte ${ }^{2}$ \\ ${ }^{1}$ Department of Earth Sciences, Faculty of Science, University of Maroua, Maroua, Cameroon \\ ${ }^{2}$ Department of Earth Sciences, Faculty of Science, University of Ngaoundéré, Ngaoundéré, Cameroon \\ Email: *daoudadawai@gmail.com
}

How to cite this paper: Boyabe, M., Dawai, D., Tchameni, R. and Tchunte, P.M.F. (2020) Petrography and Mineralogy of the Quartz and Quartz-Feldspar Sulphide Veins in the Pan-African Syenitic Massif of Guider (North Cameroon). Open Journal of Geology, 10, 235-259.

https://doi.org/10.4236/ojg.2020.103013

Received: February 1, 2020

Accepted: March 17, 2020

Published: March 20, 2020

Copyright $\odot 2020$ by author(s) and Scientific Research Publishing Inc. This work is licensed under the Creative Commons Attribution International License (CC BY 4.0).

http://creativecommons.org/licenses/by/4.0/

(c) (i) Open Access

\begin{abstract}
In the syenitic pluton of Guider (593 $\pm 4 \mathrm{Ma}$ ) in the North-West Cameroon domain of Central African Fold Belt, mineralized N-S to NE-SW vertical or sub-vertical quartz and quartz feldspar veins has been recently identified. In this contribution, we present petrography and mineralogy of these veins, in order to constrain their genesis and emplacement mechanisms based on detailed field work, petrographic studies and chemical characterization of minerals by using an electron probe microanalyser (EPMA). Field observations and vein microstructures show that the emplacement of the veins has been controlled by the dextral N-S trending strike-slip shear zones related to the regional D2 deformation phase. The results of mineralogical analysis reveal the co-presence of silicates and metallic minerals that include magnetite, ilmenite, pyrite, bismuthite, galena (very rare) and sulphide complexes (BiPbS, $\mathrm{BiAgPbS}, \mathrm{FeBiPbCuS}, \mathrm{BiFe}(\mathrm{TeS}), \mathrm{FeBiPbS}, \mathrm{BiPbCuS})$. The gangue is represented by quartz (quartz 1, quartz 2 and quartz 3), feldspars, sericite, chlorite, yellowish brown clay minerals, and hematite. The textural relationships between sulphides, quartz and alteration products show that the mineralization is essentially syn- to late- $\mathrm{D}_{2}$ and suggest that syenitic country rock and dextral shear zones have played an important role in the metallogenesis of these veins. This mineralization shows characteristics for copper-bearing calc-alkaline deposits, but differs from these by its more extensive alteration and its abundance in hematite. Substitutions of $\mathrm{Al}(\mathrm{IV})$ by $\mathrm{Si}(\mathrm{IV})$ in sericite associated with the sulphide mineralization and cataclastic deformation suggest that the temperature of trapping of the fluids is between $230^{\circ} \mathrm{C}$ and $275^{\circ} \mathrm{C}$.
\end{abstract}




\section{Keywords}

Guider, Pan-African Syenitic Intrusion, Quartz and Quartz-Feldspar Veins, Sulphide Mineralization

\section{Introduction}

Mineralization associated with more or less differentiated plutonic rocks and that associated with the concentration of hydrothermal fluids are the main primary sources of mineral resources on our planet [1] [2] [3]. Sulphides are rare and occur as ores of arsenic, tungsten, tin, bismuth, tellurium, gold, copper and antimony; quantitatively, pyrite and/or arsenopyrite are dominant. Gold is in the form of electrum or maldonite with bismuthinite and bismuth [4] [5].

Prospecting missions carried out on the Garoua East geological reconnaissance map in the North Cameroon region by the Bureau de Recherches Géologiques et Minières (BRGM) report gold, cassiterite, copper, galene-blende, rutile, ilmenite and monazite occurrences in sediments of several "mayo" or temporary watercourses [6] [7] [8]. The origin of these metals remains undetermined, especially for those located north of the Benue trough, where no metallogenic studies are carried out, compared to the Poli sector (south of the Benue trough), which has been the subject of several metallogenic studies [9] [10] [11].

Within the Pan-African syenitic massif of Guider, located north of the Benue trough, in the northern domain of the Pan-African Fold Belt in Cameroon (Figure 1), [12] has reported the presence of quartz and quartz-feldspar veins with various sulphide and oxide mineralization indices.

However, apart from the petrological and structural studies carried out on this intrusion and its country rocks by [12] [13], no studies are carried out on these quartz and quartz-feldspar veins. The goal of this paper is to carry out a petrographic, mineralogical study of the quartz and quartz-feldspar veins of Guider on the one hand, and to constrain their genesis and emplacement mechanisms on the other hand.

For this purpose, in this paper, we present the results of field and microscope observations and result of EPMA. Based on these data, we: 1) constrain the geological context of the emplacement of these veins and its mineralization; 2) discuss the origin of fluids and mineralization processes; 3) specify quartz generations and mineralization; 4) define the metal paragenesis and species chronology.

\section{Regional Geology}

The Neoproterozoic basement of Cameroon which covers a great part of the country is part of the Central African Fold Belt. This orogenic belt formed during Brasiliano/Pan-African orogeny by collision between the converging West African craton, Congo craton and Saharan Metacraton, is mainly subdivided 


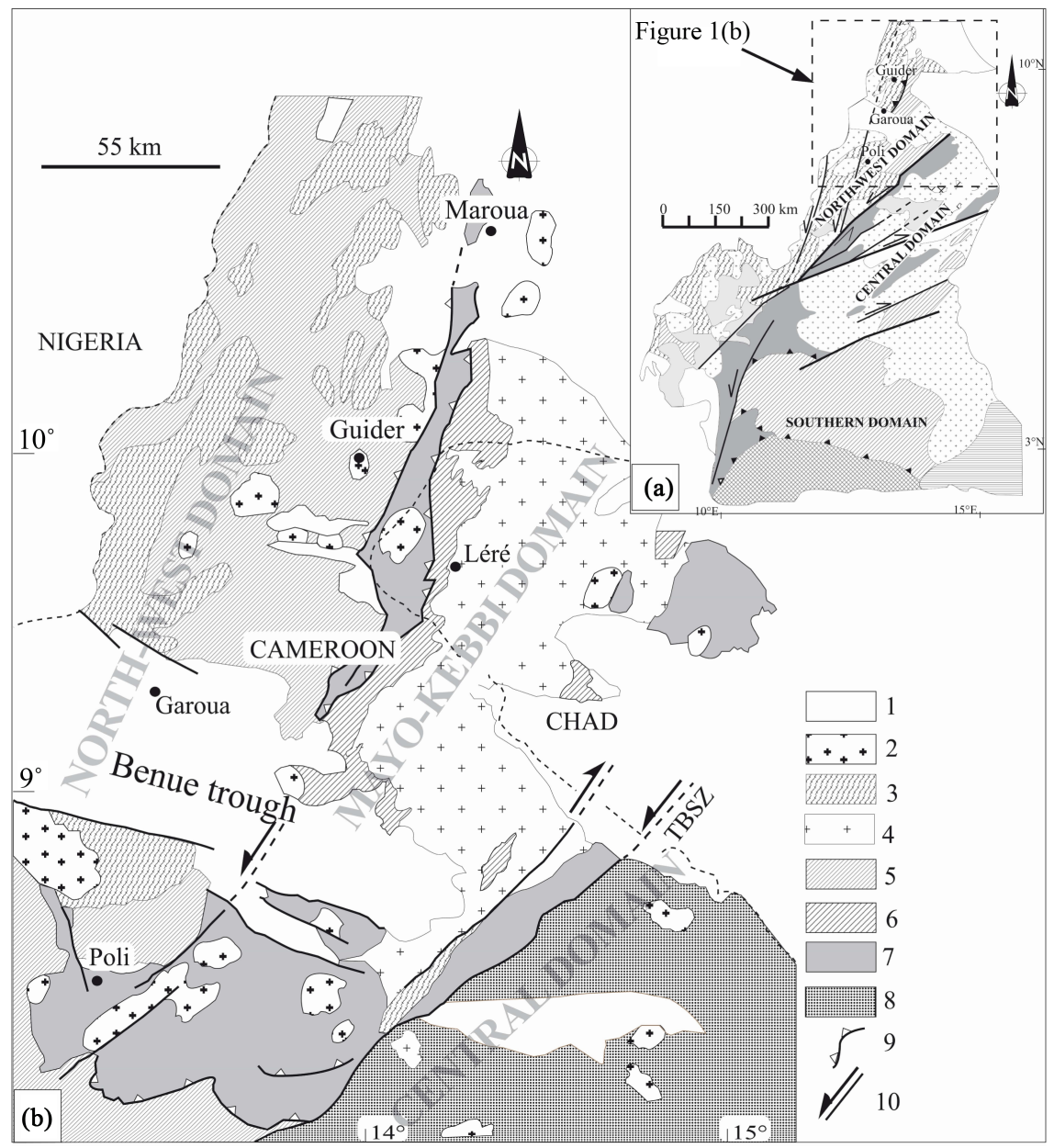

Figure 1. (a) Simplified geological map of Cameroon (modified from Toteu et al., 2001 and Tchameni et al., 2006); (b) Geological sketch map of northern Cameroon (modified from Penaye et al., 2006). (1) Post-Pan-African sediments; (2) Late to post-tectonic Pan-African granitoids; (3) Syntectonic granite; (4) Mayo-Kebbi batholith: tonalite, trondhjemite and granodiorite; (5) medium- to high-grade gneisses of the NW-Cameroon domain; (6) Mafic to intermediate complex of the Mayo-Kebbi domain (metadiorite and gabbro-diorite) and amphibolite; (7) Neoproterozoic low- to medium-grade volcano-sedimentary sequences of the Poli-Léré Group; (8) Remobilized Palaeoproterozoic Adamawa-Yadé domain; (9) Thrust front; (10) Strike slip fault: TBSZ = Tcholliré-Banyo shear zone; GGSZ = Godé-Gormaya shear zone; (11) State border.

into three lithotectonic domains in Cameroon, namely from south to north: South Cameroon domain, Central Cameroon domain or Adamaoua-Yadé domain, and North-West Cameroon domain (Figure 1(a); [14] [15] [16]). The Guider area is a part of the North-West Cameroon domain. This domain is a narrow and N-S elongate domain located between the Neoproterozoic juvenile domain of Mayo-Kébbi (SW Chad) to east and Paleoproterozoic Eastern Nigeria domain to the west (Figure 1(b)). The domain consists of the Neoproterozoic Poli Group and several generation of granitoid [14]. The Poli group is dominantly constituted of Neoproterozoic medium- to high-grade schists of volcanic to volcano-sedimentary origin, emplaced between 700 - $665 \mathrm{Ma}$ upon, or in the 
vicinity, of young magmatic arcs [17]. The granitoids, into formation of the Poli Group, are grouped into pre-, syn- to late and post-tectonic calc-alkaline granitoids dated between 660 - $540 \mathrm{Ma}$.

At the scale of the study area, geological works carried out by [13] [14] shows that the Neoproterozoic basement is primarily constitutes of composite orthogneisses, syenitic pluton and numerous dykes of varying composition including mafic dolerites dykes, felsic dykes and some quartzo-feldspathic dykes intruding the previous rocks.

Orthogneissic rocks (627-632 Ma) are dominantly made up of metadiorite, metatonalite and metagranodiorite, describe as basic to intermediate metaplutonic rocks by [18], and minor amphibolite occurring commonly as lenticular layers within orthogneiss. Because of their macroscopic features of strong deformation at solid state, they have been interpreted as a pre-tectonic granitoids. These formations suffered at least two phases of ductile deformation $\left(D_{1}\right.$ and $D_{2}$ ). $D_{1}$ fabrics are commonly overprinted by $D_{2}$ and poorly exposed. However can be seen locally at the hinge of some isoclinal folds, where the foliation $S_{1}$ is sometimes oblique to the foliation $\mathrm{S}_{2}$ of $\mathrm{D}_{2} . \mathrm{D}_{2}$ phase of deformation, widely-developed in orthogneissic rocks, is responsible for the development of an $\mathrm{S}_{2}$ foliation, $L_{2}$ lineation, folds $F_{2}$ and shear markers $C_{2}$. $S_{2}$ foliation is the most widely developed planar fabric. It is defined by felsic (quartz-plagioclase) layers alternate with biotite-hornblende layers and preferential orientation of minerals (amphibole, biotite, K-feldspar, and quartz) that are mainly oriented N-S to NNE-SSW with steep dip angles. Lineations are commonly mineral lineation defined by alignment of amphibole and plunges mainly to the SSW with a subhorizontal angle. Shear sense indicators associated with the $\mathrm{D}_{2}$ event $\left(\mathrm{C}_{2}\right)$ include asymmetric boudins, asymmetric and sigmoidal quartz aggregates or feldspar porphyroclasts and asymmetric $\mathrm{Z}$ folds revealing dextral strike-slip tectonic.

The syenitic pluton is a small elongated massif in the N-S direction of around $70 \mathrm{~km}^{2}$ in the city of Guider (Figure 2). It is dominated by pink and grey syenite with subordinated quartz-diorite. Pink and grey syenite exhibit a granular textures with abundant alkali feldspar and variable proportion of Fe-Mg minerals (amphibole and biotite). Available isotope chronology data attribute an age of $593 \pm 4 \mathrm{Ma}$ to the Guider pluton (U/Pb zircon; [13]).

The same authors, on the basis of analysis on microstructures and magnetic fabrics of this pluton and its country rocks, conclude that the emplacement this pluton is late tectonic.

\section{Sampling and Analytical Methods}

Sixteen quartz vein and twenty five quartz-feldspar vein samples were collected from outcrops; but only seven are considered in this study. There are MG3B, MG1B and MG2 for quartz veins and MG3D, MG3C, MG1C and MG1D for quartz-feldspar veins. Samples were first examined and described on a macroscopic and mesoscopic scale. Each sample was carefully shoot using a high resolution digital camera. Areas of interest were marked for thin sections making. 


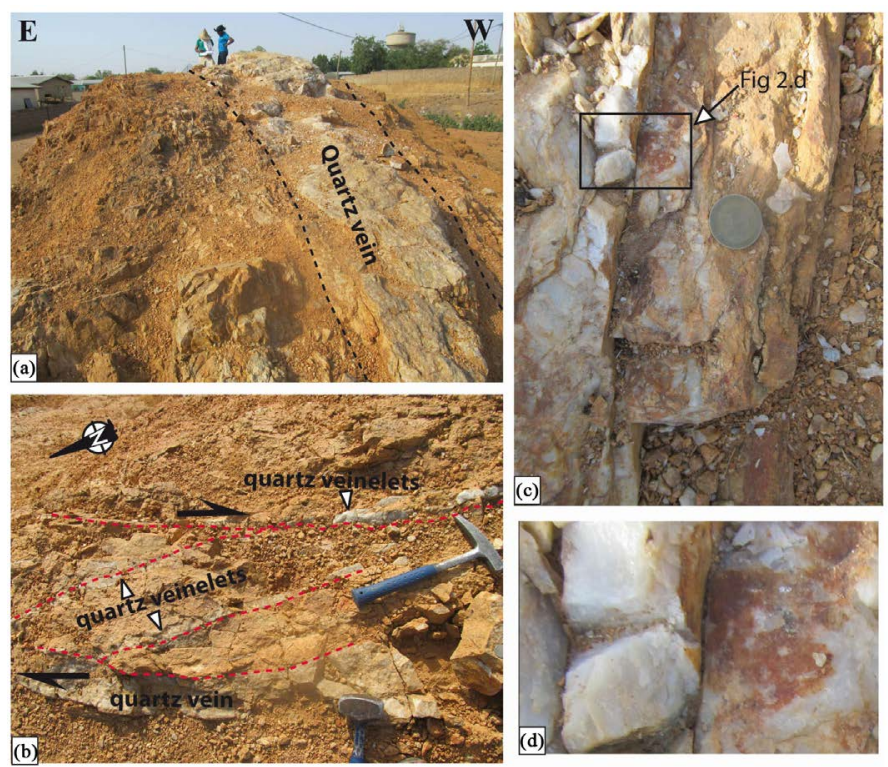

Figure 2. Field occurrences of quartz and quartz-feldspar veins within the Guider syenitic pluton. (a) Quartz-feldspar vein hosted in syenitc rocks; (b) quartz veins and veinelets crosscutting the syenitic surrounding rock and forming C/S fabrics; (c) and (d) Hematizated quartz

Textures of sulphide minerals and associated mineral assemblage were observed on polished thin sections, using the backscattered electron mode (BSE) of Hitachi S4800 scanning electron microscope (SEM), equipped with an EDS spectrometer at GeoRessources laboratory (Nancy, France) to characterize the paragenetic assemblages of the samples. The mineral chemical compositions were obtained using an electron probe microanalyser (EPMA) CAMECA SX-100 at GeoRessources laboratory (Nancy, France). The electron microprobe, type CAMECA SX100, is equipped with an electron gun $(0.2$ to $50 \mathrm{kV})$, with a tungsten filament coupled to five wavelength dispersion spectrometers, allowing the analysis of the elements from Boron to Uranium under the following analysis conditions (Primary beam: $10 \mathrm{nA}$, Acceleration voltage: $15 \mathrm{kV}$, Beam diameter: 2 $\mu \mathrm{m})$.

The result obtained is compared with a file containing the number of $\mathrm{X}$ photons of the same nature emitted under the same conditions by a compound of known composition. After correction of the matrix effects, the elementary composition of the analyzed area, generally in the range of 1 to $5 \mu \mathrm{m}^{3}$, is obtained. The composition is given in percentage of elements (\% oxides, \% weight or atomic \%). The raw results made it possible to calculate the structural formula of the minerals.

\section{Results}

\subsection{Field Observations}

The mineralized quartz-feldspar and quartz veins occur mostly at the central part of the Guider pluton. At the surface, they are characterised by 0.3 to $0.6 \mathrm{~m}$ 
thick and length of $\sim 100$ mostly directed $10^{\circ} \mathrm{N}-15^{\circ} \mathrm{E}$ steeply dip to W (Figure 2 (a)) consisting essentially of quartz and more or less altered feldspars. These veins often present tight shear planes oriented $20^{\circ} \mathrm{N}-30^{\circ} \mathrm{E}$. In the immediate surrounding rock these tight shear planes are also present in association with quartz veinlets that give to the rock a fibrous appearance (Figure 2(b)). At the scale of the sample, the rock has a reddish or yellowish colour due to the alteration of the feldspars into clay products and the presence of iron oxides. Quartz is also covered with oxides (Figure 2(c)), suggesting the hematization phenomenon that generally accompanies mineralized quartz veins.

\subsection{Petrography and Microstructure of Quartz and Quartz Feldspar Veins}

\subsubsection{Petrography}

Quartz and quartz-feldspar veins are essentially composed of quartz, more or less altered feldspar, muscovite, chlorite, oxides and sulphides showing a cataclastic texture.

Feldspar, represented by plagioclase and orthoclase are detected in samples collected at the border of quartz veins or in quartz-feldspar veins. Two generations of plagioclase are highlighted: 1) primary crystals, large in size, sub-ovoid, xenomorphic, deformed, more or less altered and sometimes pseudomorphosed by iron oxides which give a reddish appearance to the mineral (Figure 3(a)) and Figure 2) secondary small plagioclase crystals. Alkaline feldspar is abundant in
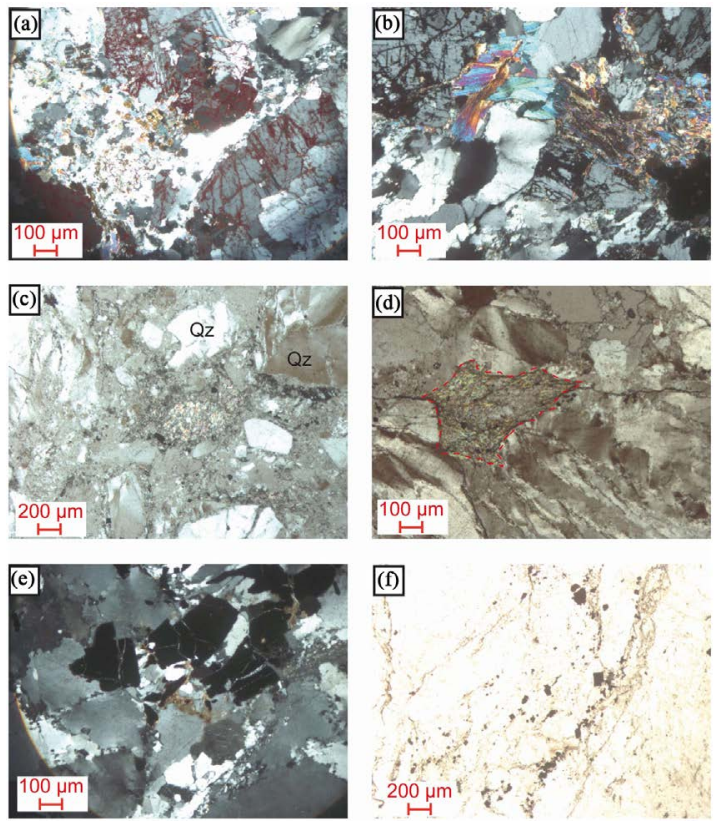

Figure 3. Photomicrographs of quartz and quartz-feldspar veins from the Guider syenitic pluton. (a) Deformed feldspar crystals showing cracks filled with hematite; (b) sericite, chlorite and oxides in the quartz-Feldspar vein; (c) Opaque minerals (oxides and sulphide) and others secondary minerals; (d) Plagioclase speumorphosed by damurite and sericite; (e) Large Sulphide in equilibrium with quartz 1; (f) secondary sulphide in the C/S planes. 
quartz-feldspar veins and rare in quartz veins. In quartz-feldspar veins, they occur as perthitic, xenomorphic, deformed and more or less pseudomorphosed by sericite (Figure $3(b)$ ). In mircoshear planes, quartz, sulphides and oxides fill the microcrack within feldspars or are associated with alteration products (Figure $3(\mathrm{c})$ ). These very tight planes give a crumbled appearance to the feldspar stretched in the microshear planes of the rock (Figure 3(d)).

Secondary muscovite (sericite) occurs in quartz fissures in textural equilibrium with sulphides and oxides or associated with alteration products of feldspar crystals. Chlorites occur as oriented lamellae or in quartz fractures and pressure shadows around opaque minerals (sulphides and oxides).

Accessory minerals are represented by sulphides and oxides. The oxides consist of hematite, magnetite and ilmenite. Hematite, the most abundant oxide in quartz-feldspar veins, occurs as large grain or as small veinlet filling microfissures in quartz and feldspar (Figure 3(b)). Magnetite occurs as small sub-automorphic grains associated with sulphides and secondary quartz in quartz-feldspar veins. Sulphides occur as cracked sub-automorphic crystals (Figure 3(e)), or small crystals scattered in rock and fractures (Figure 3(f)).

\subsubsection{Quartz Microstructure}

Textures and microstructures (extinctions, subgrains, and mineral inclusions...) are the two key parameters used for this analysis. The fact that quartz crystals are very often automorphic to subautomorphic has been very beneficial, to deduce their orientation in relation to stress. The recrystallization rate of the crystals was permit to distinguish 4 groups of quartz: quartz 1 or quartz with dominant crystallization; quartz 2 with dominant recrystallization; Quartz 3 which corresponds to late quartz veinlets that cross cut the main veins and quartz4 which shows significant shear marks.

\section{- Quartz 1}

Quartz 1 is represented by subautomorphic and subequigranular coarse grains ranging in size from millimetre to centimetre. These crystals, very often isolated, can form polygonal polycrystalline units in equilibrium with feldspar. Quartz 1 is mainly characterized by the presence of internal structures and microfractures seal or not by secondary minerals (sericite, quartz, albite, oxides and sulphides, Figure 4(a)). Intracrystalline deformation structures are marked by irregular (zoned) and regular (sweeping) undulose extinctions, deformation bands, as well as restorative structures with neoformed recrystallization grains that sometimes form chevron microfolds (Figure 4(c)), recrystallization structures that result in subgrains, and also crystal deformation structures with the development of echelon slits reflecting subsequent shear (Figure 4(c)). Large pyrite crystals (pyrite1) are associated with quartz 1 (Figure $4(\mathrm{e})$ ).

\section{- Quartz 2}

Quartz 2 consists of small sub-equigranular grains (submillimetre to millimetre) with undulose extinction and lobate margins. The grains are elongated or ribbon-shaped, with numerous subgrains, displaying strong preferred orientation 


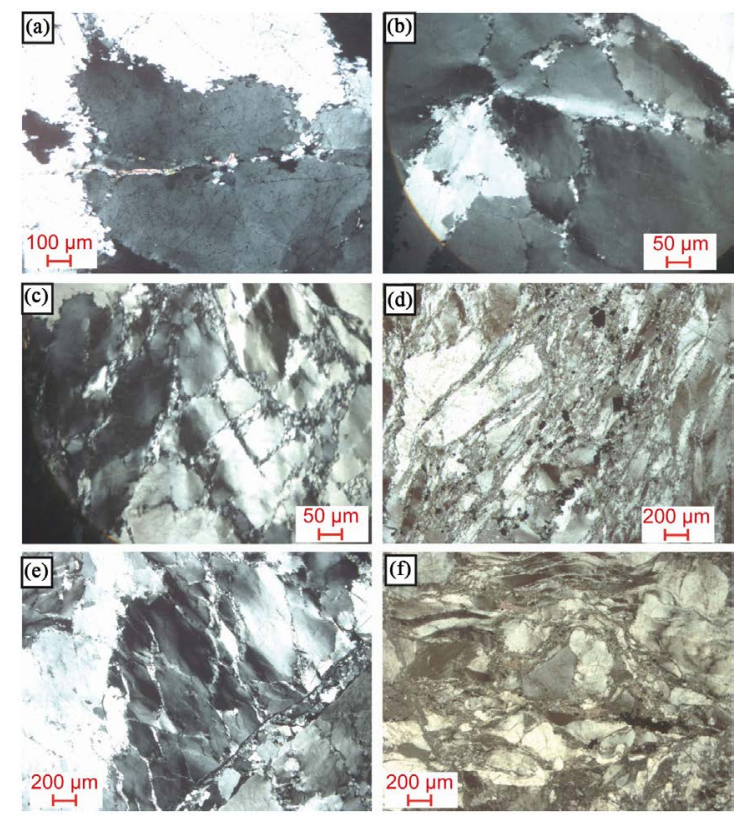

Figure 4. Microstructures of quartz of the quartz and quartz feldspar veins from the Guider syenitic pluton. (a) Quartz 1 cracked and recrystallized into rims. Cracks are filled with quartz 2 and sericite; (b) Large recrystallized quartz 1 crystals and intracrystalline deformation structures irregular (zoned) and regular (sweeping) undulose extinctions; (c) Quartz 2 recrystallized in chevron folds with an axial plane parallel to foliation, around quartz 1; (d) Quartz 2 and opaque minerals (oxides and sulphides) stretched according to foliation; (e) Veinlet of quartz 3 crosscutting quartz 1 and quartz 2; (f) Quartz 1 fish and sulphides and oxides crystallised into micorshear planes.

corresponding to the foliation (Figures 4(a)-(d)). They are associated with opaque minerals, chlorite and sericite. This paragenesis can also observed into the microcrack planes of quartz 1 (Figure 4(a)).

\section{- Quartz 3}

Quartz 3 corresponds to millimetric to centimetric quartz veinlets that cross cut quartz 1 and quartz 2 (Figure 4(e)). It is heterogranular, interlobe quartz with sweeping undulose extinction. This Quartz 3 is associated with chlorite, sericite and albite. Very rare pyrites are occasionally associated in its borders with surrounding quartz grains.

\section{- Quartz from the shear plane}

In the samples collected in shear plane, porphyroclasts of Quartz 1 and Quartz 2 are rolled, rotated and stretched with lozenge shape typical to mineral fish (Figure 4(f)). The $\mathrm{C}$ planes are slightly oblique to the foliation and allow highlighting S/C planes and dextral movements (Figure $4(\mathrm{f})$ ). The paragenesis associated with the S/C structure is quartz-sulphide \pm sericite.

\section{Mineralogy Study of Quartz and Quartz-Feldspar Veins}

\subsection{Silicates}

\subsubsection{Chlorites}

Chemical analyses of chlorites were performed in samples MG3D and MG3C 
(Table 1). In tetrahedral sites, the average Si content is between 2.5 and 2.6 atoms per half mesh. At octahedral sites, the average levels of $\mathrm{Fe}^{2+}$ (which shows the iron tendency of these chlorites) and $\mathrm{Mg}^{2+}$ are respectively 3.81 and 0.72 atoms per half mesh. The ratios $\mathrm{Fe}^{2+} /\left(\mathrm{Fe}^{2+}+\mathrm{Mg}^{2+}\right)$ between 0.83 and 8.84 for $\mathrm{Si}$ contents in the range of $2.55-2.64$ per half mesh show that these chlorites are chamosite according to the classification of [19].

Table 1. Representative electron microprobe analyses of chlorite minerals (wt\%).

\begin{tabular}{|c|c|c|c|c|c|c|}
\hline Sample & MG3D & MG3D & MG3D & MG3C & MG3C & MG3C \\
\hline Mineral & \multicolumn{6}{|c|}{ Chlorite } \\
\hline Analyse $\mathrm{N}^{\circ}$ & 47 & 48 & 49 & 71 & 72 & 80 \\
\hline $\mathrm{SiO}_{2}$ & 23.26 & 23.32 & 22.8 & 22.38 & 23.28 & 23.13 \\
\hline $\mathrm{Al}_{2} \mathrm{O}_{3}$ & 20.95 & 21.57 & 20.3 & 21.33 & 20.74 & 20.66 \\
\hline $\mathrm{TiO}_{2}$ & 0.04 & 0.12 & 0.09 & 0 & 0.08 & 0.09 \\
\hline $\mathrm{FeO}$ & 40.06 & 39.27 & 40.98 & 40.02 & 40.25 & 40.4 \\
\hline $\mathrm{MnO}$ & 0.24 & 0.22 & 0.26 & 0.29 & 0.33 & 0.29 \\
\hline $\mathrm{MgO}$ & 4.25 & 4.1 & 4.6 & 4.33 & 4.16 & 4.17 \\
\hline $\mathrm{CaO}$ & 0.08 & 0.01 & 0.01 & 0.05 & 0.03 & 0.03 \\
\hline $\mathrm{C}_{\mathrm{r} 2} \mathrm{O}_{3}$ & 0.05 & 0 & 0.03 & 0.02 & 0.03 & 0 \\
\hline $\mathrm{Na}_{2} \mathrm{O}$ & 0 & 0.04 & 0 & 0.02 & 0 & 0.02 \\
\hline $\mathrm{K}_{2} \mathrm{O}$ & 0 & 0.03 & 0.01 & 0.08 & 0 & 0 \\
\hline TOTAL & 88.93 & 88.68 & 89.08 & 88.52 & 88.9 & 88.79 \\
\hline \multicolumn{7}{|c|}{ Structural formula (28 Oxygens) } \\
\hline $\mathrm{Si}$ & 5.26 & 5.26 & 5.19 & 5.10 & 5.28 & 5.26 \\
\hline $\mathrm{Al}$ & 5.58 & 5.73 & 5.45 & 5.73 & 5.54 & 5.53 \\
\hline $\mathrm{Z}$ & 8.00 & 8.00 & 8.00 & 8.00 & 8.00 & 8.00 \\
\hline ALIV & 2.74 & 2.74 & 2.81 & 2.90 & 2.72 & 2.74 \\
\hline ALVI & 2.85 & 2.99 & 2.63 & 2.84 & 2.82 & 2.79 \\
\hline $\mathrm{Ti}$ & 0.01 & 0.02 & 0.02 & - & 0.01 & 0.02 \\
\hline $\mathrm{Fe}$ & 7.58 & 7.41 & 7.80 & 7.63 & 7.63 & 7.68 \\
\hline $\mathrm{Mn}$ & 0.05 & 0.04 & 0.05 & 0.06 & 0.06 & 0.06 \\
\hline $\mathrm{Mg}$ & 1.43 & 1.38 & 1.56 & 1.47 & 1.41 & 1.41 \\
\hline $\mathrm{Ca}$ & 0.02 & 0.00 & 0.00 & 0.01 & 0.01 & 0.01 \\
\hline $\mathrm{Cr}$ & 0.01 & - & 0.01 & 0.00 & 0.01 & - \\
\hline $\mathrm{Ni}$ & - & - & - & - & - & - \\
\hline $\mathrm{Na}$ & - & 0.02 & - & 0.01 & - & 0.01 \\
\hline $\mathrm{K}$ & - & 0.01 & 0.00 & 0.02 & - & - \\
\hline TOTAL & 33.52 & 33.60 & 33.52 & 33.78 & 33.48 & 33.50 \\
\hline $\mathrm{XFe}$ & 0.84 & 0.84 & 0.83 & 0.84 & 0.84 & 0.84 \\
\hline
\end{tabular}




\subsubsection{Feldspars}

Chemical analyses of feldspar were performed in the samples MG1C and MG3D (quartz-feldspar veins) and in the MG3B (quartz vein). Some of these analyses show that the feldspars are enriched with iron and magnesium. In quartz-feldspar veins, alkaline feldspar gives composition of Or95.76-Ab4.24 to Or97.84-Ab2.16 (Table 2). In quartz veins, the rare plagioclase crystals of the first generation have the composition of oligoclase (An17.97 to An29.23) while those of the second generation are albite (An1.92). The plagioclases of the quartz-feldspar veins are Na-oligoclase (An10.57 - 24.13).

Table 2. Representative electron microprobe analyses of feldspar minerals (wt\%).

Sample MG3D MG3D MG3D MG3D MG3B MG3B MG3B MG3B MG3D MG3D MG3D MG3D MG1C MG1C MG3D MG3D

\begin{tabular}{|c|c|c|c|c|c|c|c|c|c|c|c|c|c|c|c|c|}
\hline \multirow{2}{*}{$\begin{array}{c}\text { Mineral } \\
\text { Analyse } \mathrm{N}^{\circ}\end{array}$} & \multicolumn{7}{|c|}{ plagioclase 1} & \multicolumn{5}{|c|}{ plagioclase 2} & \multicolumn{4}{|c|}{ Alkaline Feldspar } \\
\hline & 24 & 40 & 42 & 11 & 5 & 6 & 24 & 25 & 5 & 6 & 7 & 24 & 2 & 3 & 5 & 10 \\
\hline $\mathrm{SiO}_{2}$ & 63.59 & 63.76 & 61.97 & 63.07 & 62.99 & 62.99 & 63.3 & 68.18 & 68.19 & 68.14 & 67.35 & 67.3 & 63.36 & 63.28 & 63.25 & 63.19 \\
\hline $\mathrm{Al}_{2} \mathrm{O}_{3}$ & 18.05 & 17.92 & 18.59 & 18.23 & 18.22 & 18.24 & 18.14 & 19.97 & 19.67 & 19.54 & 19.46 & 19.17 & 18.14 & 18.4 & 17.99 & 18.33 \\
\hline $\mathrm{TiO}_{2}$ & 0.03 & 0 & 0.14 & 0.01 & 0.05 & 0 & 0 & 0.03 & 0.02 & 0.07 & 0.01 & 0.01 & 0 & 0 & 0 & 0 \\
\hline $\mathrm{FeO}$ & 0.1 & 0.16 & 0.11 & 0.01 & 0.1 & 0.12 & 0.07 & 0 & 0.06 & 0.1 & 0 & 0.01 & 0.11 & 0.21 & 0.69 & 0.14 \\
\hline $\mathrm{MnO}$ & 0 & 0.07 & 0 & 0.09 & 0 & 0 & 0 & 0 & 0.01 & 0 & 0 & 0 & 0 & 0.09 & 0 & 0 \\
\hline $\mathrm{MgO}$ & 0.01 & 0.03 & 0.01 & 0.01 & 0 & 0 & 0 & 0 & 0.01 & 0 & 0 & 0.01 & 0 & 0 & 0.01 & 0.02 \\
\hline $\mathrm{CaO}$ & 3.5 & 5.86 & 3.36 & 5.45 & 6.5 & 7.8 & 5.19 & 0.41 & 0.49 & 0.47 & 0.29 & 1.18 & 0 & 0 & 0 & 0 \\
\hline $\mathrm{Cr}_{2} \mathrm{O}_{3}$ & 0 & 0.06 & 0.04 & 0 & 0 & 0.05 & 0 & 0 & 0 & 0 & 0 & 0 & 0.09 & 0.03 & 0.04 & 0.01 \\
\hline \multicolumn{17}{|l|}{$\mathrm{NiO}$} \\
\hline $\mathrm{Na}_{2} \mathrm{O}$ & 14.29 & 11.71 & 15.69 & 13.1 & 11.07 & 10.16 & 12.87 & 11.52 & 11.84 & 11.64 & 11.94 & 11.85 & 0.47 & 0.34 & 0.24 & 0.38 \\
\hline $\mathrm{K}_{2} \mathrm{O}$ & 0.03 & 0.036 & 0.042 & 0.056 & 0.34 & 0.42 & 0.34 & 0.06 & 0 & 0 & 0 & 0 & 16.13 & 16.89 & 16.56 & 16.39 \\
\hline TOTAL & 99.57 & 99.57 & 99.91 & 99.97 & 99.27 & 99.78 & 99.91 & 100.18 & 100.29 & 99.95 & 99.05 & 99.53 & 98.3 & 99.24 & 98.78 & 98.46 \\
\hline \multicolumn{17}{|l|}{$\begin{array}{l}\text { Structural } \\
\text { formula } \\
\text { (8 Oxygen) }\end{array}$} \\
\hline $\mathrm{Si}$ & 2.88 & 2.88 & 2.82 & 2.85 & 2.86 & 2.85 & 2.86 & 2.97 & 2.98 & 2.98 & 2.98 & 2.97 & 2.99 & 2.97 & 2.98 & 2.98 \\
\hline $\mathrm{Al}$ & 0.96 & 0.95 & 1 & 0.97 & 0.97 & 0.97 & 0.97 & 1.03 & 1.01 & 1.01 & 1.01 & 1 & 1.01 & 1.02 & 1 & 1.02 \\
\hline $\mathrm{Fe}$ & 0 & 0.01 & 0 & 0 & 0 & 0 & 0 & - & 0 & 0 & - & 0 & 0 & 0.01 & 0.03 & 0.01 \\
\hline $\mathrm{Ca}$ & 0.17 & 0.28 & 0.16 & 0.26 & 0.32 & 0.38 & 0.25 & 0.02 & 0.02 & 0.02 & 0.01 & 0.06 & - & - & - & - \\
\hline $\mathrm{Na}$ & 1.25 & 1.03 & 1.38 & 1.15 & 0.97 & 0.89 & 1.13 & 0.97 & 1 & 0.99 & 1.02 & 1.01 & 0.04 & 0.03 & 0.02 & 0.03 \\
\hline $\mathrm{K}$ & 0 & 0 & 0 & 0 & 0.02 & 0.02 & 0.02 & 0 & - & - & - & - & 0.97 & 1.01 & 1 & 0.99 \\
\hline TOTAL & 5.27 & 5.15 & 5.37 & 5.24 & 5.15 & 5.12 & 5.23 & 5 & 5.02 & 5 & 5.03 & 5.04 & 5.01 & 5.04 & 5.03 & 5.02 \\
\hline$\% A n$ & 11.91 & 21.63 & 10.57 & 18.65 & 24.13 & 29.23 & 17.97 & 1.92 & 2.24 & 2.18 & 1.32 & 5.22 & - & - & - & - \\
\hline$\% A b$ & 87.97 & 78.21 & 89.28 & 81.12 & 74.37 & 68.9 & 80.63 & 97.74 & 97.76 & 97.82 & 98.68 & 94.78 & 4.24 & 2.97 & 2.16 & 3.4 \\
\hline$\% O r$ & 0.12 & 0.16 & 0.16 & 0.23 & 1.5 & 1.87 & 1.4 & 0.33 & - & - & - & - & 95.76 & 97.03 & 97.84 & 96.6 \\
\hline
\end{tabular}




\subsubsection{White Micas}

White micas are analyzed in samples MG1B (quartz vein) and MG3D and MG1D (quartz-feldspar vein), the results are recorded in Table 3. They are characterized by their low $\mathrm{Ti}(0.02-0.29)$ and $\mathrm{Na}(0.02-0.06)$ content compared to $\mathrm{Mg}(0.23-0.31)$, suggesting that they are secondary muscovites according to the classification of [20]. Micas are characterized by a correlative substitution between $\mathrm{Si}^{\mathrm{IV}}$ and $\mathrm{Al}^{\mathrm{IV}}$ (Figure 5(b)) and between $\mathrm{Fe}^{2+}$ and $\mathrm{Al}^{\mathrm{VI}}$ (Figure 5(b)).

Table 3. Representative electron microprobe analyses of white micas minerals (wt\%).

\begin{tabular}{|c|c|c|c|c|c|c|c|}
\hline Sample & MG1B & MG1B & MG1B & MG1B & MG3D & MG3D & MG1D \\
\hline Analyse $\mathrm{N}^{\circ}$ & 3 & 5 & 6 & 18 & 23 & 27 & 29 \\
\hline $\mathrm{SiO}_{2}$ & 50.1 & 48.12 & 47.79 & 47.07 & 47.85 & 47.37 & 47.77 \\
\hline $\mathrm{Al}_{2} \mathrm{O}_{3}$ & 32.38 & 32.4 & 31.79 & 30.35 & 31.47 & 30.94 & 29.76 \\
\hline $\mathrm{TiO}_{2}$ & 0.22 & 0.37 & 0.98 & 1.95 & 2.04 & 1.37 & 2.87 \\
\hline $\mathrm{FeO}$ & 3.38 & 3.04 & 3.76 & 4.07 & 3.24 & 3.81 & 3.66 \\
\hline $\mathrm{MnO}$ & 0 & 0 & 0.08 & 0.02 & 0.12 & 0.06 & 0 \\
\hline $\mathrm{MgO}$ & 1.25 & 1.27 & 1.5 & 1.57 & 1.17 & 1.35 & 1.55 \\
\hline $\mathrm{CaO}$ & 0 & 0 & 0.04 & 0.02 & 0.03 & 0.04 & 0 \\
\hline $\mathrm{Cr}_{2} \mathrm{O}_{3}$ & 0 & 0.04 & 0.07 & 0 & 0.02 & 0.01 & 0.07 \\
\hline $\mathrm{Na}_{2} \mathrm{O}$ & 0.14 & 0.21 & 0.22 & 0.15 & 0.1 & 0.08 & 0.08 \\
\hline $\mathrm{K}_{2} \mathrm{O}$ & 9.07 & 10.56 & 10.21 & 10.8 & 10.26 & 10.45 & 10.64 \\
\hline TOTAL & 96.54 & 96.01 & 96.44 & 96 & 96.3 & 95.48 & 96.4 \\
\hline \multicolumn{8}{|c|}{$\begin{array}{l}\text { Structural formula } \\
\text { (8 Oxygen) }\end{array}$} \\
\hline $\mathrm{Si}$ & 6.55 & 6.4 & 6.35 & 6.33 & 6.35 & 6.37 & 6.38 \\
\hline $\mathrm{Al}$ & 4.99 & 5.08 & 4.98 & 4.81 & 4.93 & 4.91 & 4.68 \\
\hline $\mathrm{Z}$ & 8 & 8 & 8 & 8 & 8 & 8 & 8 \\
\hline ALIV & 1.45 & 1.6 & 1.65 & 1.67 & 1.65 & 1.63 & 1.62 \\
\hline ALVI & 3.53 & 3.47 & 3.33 & 3.14 & 3.28 & 3.28 & 3.06 \\
\hline $\mathrm{Ti}$ & 0.02 & 0.04 & 0.1 & 0.2 & 0.2 & 0.14 & 0.29 \\
\hline $\mathrm{Fe}$ & 0.37 & 0.34 & 0.42 & 0.46 & 0.36 & 0.43 & 0.41 \\
\hline $\mathrm{Mn}$ & - & - & 0.01 & 0 & 0.01 & 0.01 & - \\
\hline $\mathrm{Mg}$ & 0.24 & 0.25 & 0.3 & 0.31 & 0.23 & 0.27 & 0.31 \\
\hline $\mathrm{Ca}$ & - & - & 0.01 & 0 & 0 & 0.01 & - \\
\hline $\mathrm{Cr}$ & - & 0 & 0.01 & - & 0 & 0 & 0.01 \\
\hline $\mathrm{Ni}$ & - & - & - & - & - & - & - \\
\hline $\mathrm{Na}$ & 0.04 & 0.05 & 0.06 & 0.04 & 0.03 & 0.02 & 0.02 \\
\hline $\mathrm{K}$ & 1.51 & 1.79 & 1.73 & 1.85 & 1.74 & 1.79 & 1.81 \\
\hline TOTAL & 26.7 & 27.02 & 26.93 & 26.82 & 26.79 & 26.85 & 26.59 \\
\hline $\mathrm{XFe}$ & 0.6 & 0.57 & 0.58 & 0.59 & 0.61 & 0.61 & 0.57 \\
\hline
\end{tabular}




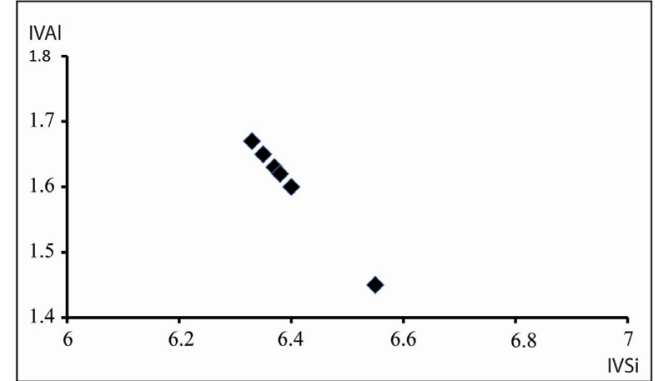

(a)

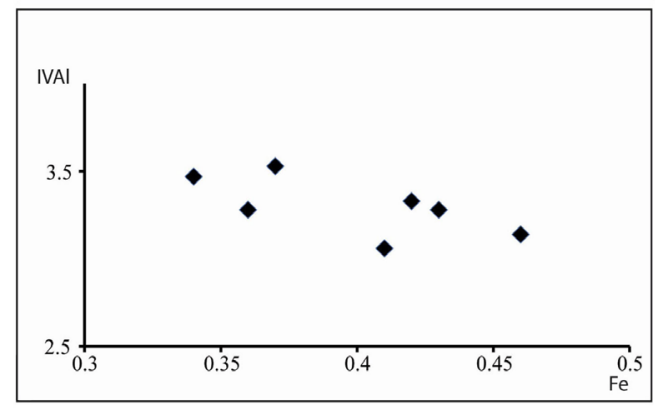

(b)

Figure 5. Diagrams showing correlative substitution (b) between $\mathrm{Si}^{\mathrm{IV}}$ and $\mathrm{Al}^{\mathrm{IV}}$. and (b) between $\mathrm{Fe}^{2+}$ and $\mathrm{Al}^{\mathrm{VI}}$.

\subsection{Oxides}

Oxides are analysed in quartz veins and quartz-feldspar samples. In quartz-feldspar veins, oxides are represented by hematite, the most abundant oxide, magnetite and ilmenite. Ilmenite $\left(81.74 \%\right.$ to $\left.99.04 \% \mathrm{TiO}_{2}\right)$ is found in quartz veins and quartz-feldspar veins with elongated crystals. Hematite crystals are not pure. In addition to iron $(63.2 \%-72.7 \% \mathrm{FeO})$, analyses show traces of silica, aluminum and potassium, suggesting that hematite is a product of hydrothermalism that has invaded feldspar. Indeed, part of the hematite comes from the transformation of magnetite and pyrites. Magnetite has been observed as inclusions in sulphides mainly in pyrite and rarely in bismuthinite. It was probably formed at the same time as the early pyrite with which it is in equilibrium in both types of veins. It is almost completely transformed into hematite during hydrothermal alteration.

\subsection{Sulphides}

Electronic microprobe analyses show that sulphides are represented by pyrite $\left(\mathrm{FeS}_{2}\right)$ in quartz and quartz-feldspar veins, bismuthinite $\left(\mathrm{Bi}_{2} \mathrm{~S}_{3}\right)$, galena $(\mathrm{PbS})$ and complex sulphides. SEM images (Figure 6) highlight the textural relationship between the different types of analysed sulphides.

\subsubsection{Pyrite}

Pyrite constitutes about $30 \%$ to $55 \%$ of all metal components. However, it can locally constitute $70 \%$ to $80 \%$ of the sulphides. In the quartz-feldpath (MG1D) sample, pyrites form small, automorphic or sub-automorphic crystal clusters 


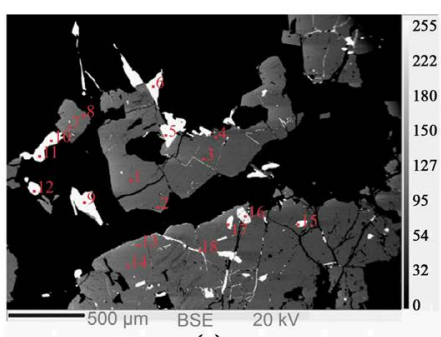

(a)

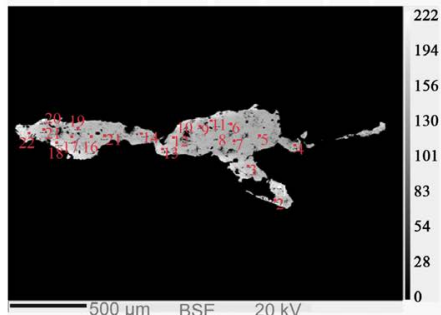

(b)

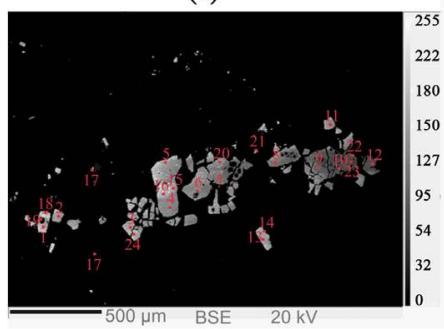

(c)

Figure 6. SEM images of sulphides. (a) Bismuthinite $\left(\mathrm{N}^{\circ} 5,6,9,10,10,11\right.$ and 12$)$ as inclusions or in cracks $\left(\mathrm{N}^{\circ} 15,16,17\right.$ and 18) in large pyrite crystal (Sample MG1B of quartz vein); (b) Bismuthinite presents as large pyrite crystal (Sample MG2 of quartz vein;) of quartz vein; (c) Concentration of pyrite with small crystals of $\mathrm{FeBiPb}( \pm \mathrm{Cu})\left(\mathrm{N}^{\circ} 14,15,16\right.$, $20,22,24)$ and $\mathrm{FeBi}( \pm \mathrm{Te})\left(\mathrm{N}^{\circ} 18,19,23\right)$ complex sulphide in cracks and inclusion (sample MG1D of quartz-feldspar vein).

frequently associated with phyllosilicates (micas and chlorite). They can result from the destabilization of chlorites to form phengites, which would release iron. In quartz veins, pyrites have two habitus: 1) pyrite1 are fractured and in equilibrium with quartz 1 and 2) pyrite2, generally of small size, are automorphic crystals associated with quartz 2 and Quartz 3. First generation pyrites contribute to the genesis of other sulphides. These pyrites are composed mainly of iron (33.25 - $33.63 \mathrm{wt} \%)$ and sulphur (66.36 - $66.74 \mathrm{wt} \%)$ and represent on average $99.94 \mathrm{wt} \%$ of the percentage sum of the other analyzed elements in the sample MG1B (Quartz-vein). In the sample MG1D of quart-feldspar vein, the pyrites are composed mainly of iron (26.12 - $33.14 \mathrm{wt} \%)$ and sulphur (59.68 - 66.72 wt\%); trace elements are abundant and represented by lead, bismuth, telluride and rarely silver and copper (Table 4).

\subsubsection{Bismuthinite}

Bismuthinite is the second most abundant type of sulphide after pyrite in the analyzed rocks. The mineral has a higher reflectivity than pyrites, which makes it possible to distinguish them from the latter. In quartz veins (MG1B, MG2), 
Table 4. Representative electron microprobe analyses of pyrite minerals (wt\%).

\begin{tabular}{|c|c|c|c|c|c|c|c|c|c|c|c|c|c|c|c|c|c|c|c|c|c|c|}
\hline Sample & & & & MG1B & & & & & & & & & & & MG1D & & & & & & & \\
\hline $\begin{array}{c}\text { Analyse } \\
\mathrm{N}^{\circ}\end{array}$ & 1 & 2 & 3 & 4 & 7 & 8 & 14 & 1 & 2 & 3 & 4 & 5 & 6 & 7 & 8 & 10 & 11 & 12 & 13 & 19 & 22 & 23 \\
\hline S & 66.36 & 66.53 & 66.41 & 66.5 & 66.53 & 66.49 & 66.74 & 66.57 & 66.42 & 66.59 & 66.66 & 67.07 & 66.47 & 66.63 & 66.69 & 66.72 & 66.55 & 66.63 & 66.62 & 62.9 & 63.18 & 62.48 \\
\hline $\mathrm{Fe}$ & 33.63 & 33.44 & 33.54 & 33.48 & 33.4 & 33.43 & 33.26 & 33.34 & 33.41 & 33.15 & 32.95 & 32.86 & 33.43 & 33.24 & 33.23 & 33.23 & 33.26 & 33.34 & 33.35 & 31.15 & 26.12 & 32.09 \\
\hline Co & 0.00 & 0.01 & 0.02 & 0.01 & 0.00 & 0.00 & 0.00 & 0.05 & 0.12 & 0.2 & 0.35 & 0.01 & 0.07 & 0.09 & 0.02 & 0.00 & 0.18 & 0.00 & 0.02 & 0.87 & 0.01 & 0.00 \\
\hline $\mathrm{Ni}$ & 0.00 & 0.00 & 0.00 & 0.00 & 0.00 & 0.00 & 0.00 & 0.00 & 0.00 & 0.01 & 0.00 & 0.00 & 0.00 & 0.00 & 0.00 & 0.00 & 0.00 & 0.00 & 0.00 & 0.00 & 0.00 & 0.00 \\
\hline $\mathrm{Cu}$ & 0.00 & 0.00 & 0.00 & 0.00 & 0.00 & 0.01 & 0.00 & 0.00 & 0.00 & 0.00 & 0.00 & 0.00 & 0.00 & 0.00 & 0.00 & 0.00 & 0.00 & 0.00 & 0.00 & 0.00 & 0.92 & 0.00 \\
\hline $\mathrm{Zn}$ & 0.00 & 0.00 & 0.00 & 0.00 & 0.00 & 0.00 & 0.00 & 0.00 & 0.00 & 0.00 & 0.00 & 0.00 & 0.00 & 0.00 & 0.02 & 0.00 & 0.00 & 0.01 & 0.00 & 0.00 & 0.00 & 0.00 \\
\hline As & 0.00 & 0.00 & 0.00 & 0.01 & 0.04 & 0.01 & 0.00 & 0.01 & 0.00 & 0.00 & 0.00 & 0.00 & 0.00 & 0.00 & 0.00 & 0.05 & 0.01 & 0.00 & 0.00 & 0.00 & 0.00 & 0.00 \\
\hline $\mathrm{Ag}$ & 0.00 & 0.00 & 0.00 & 0.00 & 0.00 & 0.01 & 0.00 & 0.00 & 0.01 & 0.00 & 0.00 & 0.00 & 0.00 & 0.00 & 0.00 & 0.00 & 0.00 & 0.00 & 0.00 & 0.00 & 1.11 & 0,00 \\
\hline $\mathrm{Sb}$ & 0.00 & 0.00 & 0.00 & 0.00 & 0.00 & 0.00 & 0.00 & 0.00 & 0.00 & 0.00 & 0.00 & 0.00 & 0.00 & 0.00 & 0.00 & 0.00 & 0.00 & 0.00 & 0.00 & 0.00 & 0.00 & 0.00 \\
\hline $\mathrm{Au}$ & 0.00 & 0.00 & 0.00 & 0.00 & 0.00 & 0.00 & 0.00 & 0.00 & 0.00 & 0.00 & 0.00 & 0.00 & 0.00 & 0.00 & 0.00 & 0.00 & 0.00 & 0.00 & 0.00 & 0.00 & 0.00 & 0.00 \\
\hline $\mathrm{Pb}$ & 0.00 & 0.03 & 0.03 & 0.00 & 0.00 & 0.06 & 0.00 & 0.02 & 0.01 & 0.05 & 0.04 & 0.05 & 0.03 & 0.04 & 0.04 & 0.00 & 0.00 & 0.02 & 0.00 & 0.07 & 2.16 & 0.03 \\
\hline $\mathrm{Bi}$ & 0.00 & 0.00 & 0.00 & 0.00 & 0.00 & 0.00 & 0.00 & 0.00 & 0.00 & 0.00 & 0.00 & 0.00 & 0.00 & 0.00 & 0.00 & 0.00 & 0.00 & 0.00 & 0.00 & 2.46 & 6.45 & 5.4 \\
\hline $\mathrm{Se}$ & & & & & 0.00 & n.d. & & 0.00 & 0.02 & 0.00 & 0.01 & 0.00 & 0.00 & 0.00 & 0.00 & 0.00 & 0.00 & 0.00 & 0.00 & 0.00 & 0.02 & 0.00 \\
\hline $\mathrm{Te}$ & & & & & 0.02 & & & 0.01 & 0.01 & 0.00 & 0.00 & 0.00 & 0.00 & 0.00 & 0.00 & 0.00 & 0.00 & 0.00 & 0.00 & 2.54 & 0.04 & 0.00 \\
\hline Total & 99.99 & 100.01 & 100.00 & 100.00 & 99.97 & 100.01 & 100.00 & 99.99 & 99.97 & 100.00 & 100.00 & 99.99 & 100.00 & 100.00 & 100.00 & 100.00 & 100.00 & 100.00 & 99.99 & 97.45 & 99.95 & 100.00 \\
\hline
\end{tabular}

bismuthinite grains crystallize in intragranular or intergranular microcracks and borders of pyrite (Figure 6(a)). In the MG1B sample, rare large crystals in equilibrium with pyrite are observed. The analyzed crystals have Bismuth and Sulphur contents ranging from 31.31 to $38.65 \mathrm{wt} \%$ and 57.52 to $60.55 \mathrm{wt} \%$ respectively (Table 5). In addition to Bismuth and sulphur, the analyzed crystals still contain traces of lead (1.07 - $4.62 \mathrm{wt} \%)$, copper (0.99 - $5.45 \mathrm{wt} \%)$ and rarely gold $(\leq 0.15 \mathrm{wt} \%)$ and selenium $(\leq 0.06 \mathrm{wt} \%)$. Traces of Se suggest a partial substitution of $\mathrm{S}^{2-}$ by $\mathrm{Se}^{2-}$.

\subsubsection{Galena}

Galena is detected in the sample of the MG2 quartz vein. It crystallizes in the cracks of the pyrite. Due to the very small size of these crystals, only one analysis is performed. The crystal has a content of $77.66 \mathrm{wt} \% \mathrm{~Pb}$ and $16.38 \mathrm{wt} \%$ sulphur (Table 6). Iron and bismuth are in trace form with values of $2.51 \mathrm{wt} \%$ and 2.85 wt $\%$ respectively.

\subsubsection{Complex Sulphides}

Complex sulphides correspond to sulphides in which we have the combination of several elements. Referring to the literature, it has been difficult for us to classify them either as sulfosalts or sulfides. We group them here according to the content of the elements. Thus, two groups are highlighted: complex bismuth and lead sulphides (BiPbS), complex bismuth and iron sulphides $(\mathrm{BiFe}(\mathrm{S}))$ or $(\mathrm{BiFe}$ $(\mathrm{S}, \mathrm{Te}))$. 
Table 5. Representative electron microprobe analyses of bismuthinite (wt\%).

\begin{tabular}{|c|c|c|c|c|c|c|c|c|c|c|c|c|c|c|c|c|c|c|c|c|c|c|}
\hline \multirow{2}{*}{$\begin{array}{c}\text { Sample } \\
\begin{array}{c}\text { Analyse } \\
\mathrm{N}^{\circ}\end{array}\end{array}$} & \multicolumn{6}{|c|}{ MG1B } & \multicolumn{16}{|c|}{ MG2 } \\
\hline & 5 & 6 & 9 & 10 & 11 & 12 & 2 & 3 & 4 & 5 & 6 & 9 & 10 & 11 & 12 & 13 & 15 & 16 & 17 & 18 & 20 & 22 \\
\hline$S$ & 59.74 & 59.63 & 59.98 & 57.77 & 59.72 & 59.62 & 58.83 & 59.29 & 58.36 & 59.89 & 59.69 & 59.92 & 59.48 & 59.09 & 58.4 & 58.97 & 59.22 & 58.1 & 59.88 & 59.07 & 60.55 & 57.62 \\
\hline $\mathrm{Fe}$ & 0.00 & 0.00 & 0.00 & 0.00 & 0.00 & 0.00 & 0.00 & 0.00 & 0.00 & 0.00 & 0.00 & 0.00 & 0.01 & 0.00 & 0.00 & 0.00 & 0.00 & 0.00 & 0.00 & 0.07 & 0.00 & 0.00 \\
\hline $\mathrm{Ni}$ & 0.00 & 0.00 & 0.00 & 0.00 & 0.00 & 0.00 & 0.00 & 0.00 & 0.00 & 0.00 & 0.00 & 0.00 & 0.00 & 0.00 & 0.00 & 0.00 & 0.00 & 0.00 & 0.00 & 0.00 & 0.00 & 0.00 \\
\hline $\mathrm{Cu}$ & 1.32 & 2.37 & 0.99 & 5.45 & 1.46 & 1.35 & 4.56 & 1.96 & 2.3 & 1.93 & 2.04 & 1.33 & 1.64 & 3.39 & 3.93 & 1.21 & 2.68 & 3.61 & 1.29 & 1,00 & 1.07 & 3.34 \\
\hline $\mathrm{Zn}$ & 0.00 & 0.00 & 0.00 & 0.00 & 0.00 & 0.00 & 0.00 & 0.00 & 0.00 & 0.00 & 0.00 & 0.00 & 0.00 & 0.01 & 0.00 & 0.00 & 0.00 & 0.00 & 0.00 & 0.00 & 0.00 & 0.00 \\
\hline As & 0.00 & 0.00 & 0.00 & 0.00 & 0.00 & 0.00 & 0.00 & 0.00 & 0.00 & 0.00 & 0.00 & 0.00 & 0.04 & 0,00 & 0.00 & 0.00 & 0.00 & 0.00 & 0.00 & 0.00 & 0.00 & 0.00 \\
\hline $\mathrm{Sb}$ & 0.00 & 0.00 & 0.00 & 0.00 & 0.00 & 0.00 & 0.00 & 0.00 & 0.00 & 0.00 & 0.00 & 0.00 & 0.00 & 0.00 & 0.00 & 0.00 & 0.00 & 0.00 & 0.00 & 0.00 & 0.00 & 0.00 \\
\hline $\mathrm{Au}$ & 0.00 & 0.00 & 0.00 & 0.00 & 0.00 & 0.00 & 0.00 & 0.00 & 0.12 & 0.06 & 0.00 & 0.00 & 0.14 & 0.15 & 0.14 & 0.00 & 0.00 & 0.05 & 0.05 & 0.09 & 0.02 & 0.00 \\
\hline $\mathrm{Pb}$ & 1.31 & 2.24 & 1.07 & 5.47 & 1.56 & 1.61 & 4.62 & 1.92 & 2.31 & 1.79 & 2.07 & 1.33 & 1.57 & 3.35 & 3.91 & 1.2 & 2.65 & 3.75 & 1.27 & 1.1 & 1.07 & 3.49 \\
\hline $\mathrm{Bi}$ & 37.56 & 35.76 & 37.96 & 31.31 & 37.2 & 37.39 & 31.99 & 36.8 & 36.91 & 36.33 & 36.16 & 37.42 & 37.12 & 33.99 & 33.56 & 38.6 & 35.44 & 34.39 & 37.51 & 38.65 & 37.28 & 35.46 \\
\hline $\mathrm{Se}$ & 0.07 & 0,00 & 0,00 & 0.00 & 0.06 & 0.03 & 0.00 & 0.00 & 0.00 & 0.00 & 0.00 & 0.01 & 0.00 & 0.00 & 0.06 & 0.00 & 0.00 & 0.01 & 0.00 & 0.02 & 0.01 & 0,00 \\
\hline $\mathrm{Te}$ & 0.00 & 0.00 & 0.00 & 0.00 & 0.00 & 0.00 & 0.00 & 0.00 & 0.00 & 0.00 & 0.00 & 0.00 & 0.00 & 0.00 & 0.00 & 0.00 & 0.00 & 0.00 & 0.00 & 0.00 & 0.00 & 0.00 \\
\hline Total & 99.93 & 100.00 & 100.00 & 100.00 & 99.94 & 99.97 & 100.00 & 100.00 & 100.00 & 100.01 & 100.00 & 100.00 & 100.00 & 99.99 & 99.94 & 100.00 & 99.99 & 99.98 & 100.00 & 99.98 & 99.99 & 100.00 \\
\hline
\end{tabular}

Table 6. Representative electron microprobe analyses of complex sulphides and galena (wt\%).

\begin{tabular}{|c|c|c|c|c|c|c|c|c|c|c|c|}
\hline Sample & MG1D & MG1D & MG1D & MG1D & MG1B & MG1B & MG1B & MG1D & MG1D & MG1D & MG2 \\
\hline Mineral & \multicolumn{10}{|c|}{ complex sulphides } & galena \\
\hline Analyse $\mathrm{N}^{\circ}$ & 14 & 15 & 16 & 21 & 16 & 17 & 18 & 17 & 20 & 24 & 12 \\
\hline$S$ & 62.2 & 57.38 & 61.62 & 54.57 & 45.99 & 47.85 & 53.71 & 54.8 & 56.81 & 57.46 & 16.38 \\
\hline $\mathrm{Fe}$ & 26.88 & 18.21 & 21.2 & 0.00 & 0.32 & 0.36 & 0.14 & 0.00 & 9.79 & 12.33 & 2.51 \\
\hline Co & 0.00 & 0.31 & 0.19 & 0.00 & 0.00 & 0.00 & 0.00 & 0.00 & 0.00 & 0.00 & 0.00 \\
\hline $\mathrm{Ni}$ & 0.00 & 0.00 & 0.00 & 0.00 & 0.00 & 0.00 & 0.00 & 0.00 & 0.00 & 0.00 & 0.00 \\
\hline $\mathrm{Cu}$ & 0.15 & 0.12 & 0.00 & 0.68 & 11.8 & 5.99 & 10.21 & 8.99 & 4.88 & 0.22 & 0.00 \\
\hline $\mathrm{Zn}$ & 0.00 & 0.00 & 0.00 & 0.00 & 0.00 & 0.00 & 0.00 & 0.00 & 0.00 & 0.00 & 0.00 \\
\hline As & 0.00 & 0.00 & 0.00 & 0.00 & 0.00 & 0.00 & 0.00 & 0.00 & 0.00 & 0.00 & 0.00 \\
\hline $\mathrm{Ag}$ & 2.16 & 4.13 & 0.00 & 7.59 & 0.00 & 0.03 & 0.00 & 0.00 & 0.00 & 3.77 & 0.01 \\
\hline $\mathrm{Sb}$ & 0.00 & 0.00 & 0.00 & 0.00 & 0.00 & 0.00 & 0.00 & 0.00 & 0.00 & 0.00 & 0.00 \\
\hline $\mathrm{Au}$ & 0.00 & 0.26 & 0.00 & 0.00 & 0.00 & 0.00 & 0.00 & 0.00 & 0.00 & 0.07 & 0.00 \\
\hline $\mathrm{Pb}$ & 2.21 & 5.63 & 5.71 & 9.94 & 12.66 & 10.1 & 11.04 & 9.7 & 5.09 & 8.06 & 77.66 \\
\hline $\mathrm{Bi}$ & 6.39 & 13.53 & 11.27 & 27.22 & 29.23 & 35.67 & 24.9 & 26.48 & 23.39 & 18.06 & 2.85 \\
\hline $\mathrm{Se}$ & 0.00 & 0.00 & 0.00 & 0.00 & 0.00 & 0.00 & 0.00 & 0.03 & 0.00 & 0.00 & 0.00 \\
\hline $\mathrm{Te}$ & 0.00 & 0.68 & 0.00 & 0.00 & 0.00 & 0.00 & 0.00 & 0.00 & 0.00 & 0.09 & 0.09 \\
\hline Total & 99.99 & 99.58 & 99.99 & 100.00 & 100.00 & 100.00 & 100.00 & 99.97 & 99.96 & 99.97 & 99.50 \\
\hline
\end{tabular}


Complex sulphides are analyzed in the quartz-feldspar veins and quartz veins represented by the MG1C and MG1D and MG2 respectively (Table 6). The crystals are elongated according to foliation $\mathrm{S}_{2}$ or in pyrite cracks. In addition to the two cations $\mathrm{Pb}^{2+}(2.21-12.66 \mathrm{wt} \%)$ and $\mathrm{Bi}^{3+}(6.39-35.67 \mathrm{wt} \%)$, we note the presence of $\mathrm{Cu}(\leq 11.8 \mathrm{wt} \%)$, which suggests the presence of aïkinite $\left(\mathrm{PbCuBiS}_{3}\right)$. Iron is abundant in sample MG1D (9.79 - $26.88 \mathrm{wt} \%)$ but rare in MG1B (0.14 $0.36 \mathrm{wt} \%)$. Gold is present in several crystals, but as a trace $(\leq 0.26 \mathrm{wt} \%)$ in the MG1D sample where it is included in the pyrite. The transfer of $\mathrm{Bi}$ and $\mathrm{Pb}$ contents in a diagram shows a positive correlation between these two elements, suggesting substitution between them (Figure 7). As the charges are not identical, it is probably necessary to consider another substitution for the mineral to be neutral. Otherwise, some sites will not be saturated, which characterizes many sulphides and sulphosalts (Cox, 1987).

\section{Discussions}

\subsection{Geological Context}

The study area, in the locality of Guider, is located in the northern domain of the CPAC in Cameroon. This area consists of orthogneissic basement dated at 627 632 [12], intruded by syenitic intrusion dated at $593 \pm 4 \mathrm{Ma}$ [13]. All of these metamorphic and plutonic rocks are cross cutting by quartz and quartz-feldspar veins. At least three deformation phases are highlighted in this sector: $D_{1}$ phase, in orthogneiss and amphibolites where it is transposed by $D_{2}$ phase. The $D_{2}$ phase is materialized by steep foliation with N-S to NNE-SSW direction with mineral lineations $\left(\mathrm{L}_{2}\right)$ shallowly plunging and dextral markers attesting a transpressive and dextral regime of this D2 in the Guider area [12]. According to [13] the NE-trending and dextral transpressive shear zone that acted in the Guider area ended after the emplacement of the Guider syenitic pluton.

Petrographic and mineralogical studies distinguish two types of quartz and quartz-feldspar veins: non-mineralized veins and mineralized veins. The $10^{\circ} \mathrm{N}$ $15^{\circ} \mathrm{E}$ orientation of the mineralized veins, the $20^{\circ} \mathrm{N}-30^{\circ} \mathrm{E}$ orientation of the veinlets and the microstructure of the veins suggest that the emplacement of mineralized veins took place before the end of transpressive deformation in its syenitic country rocks. We suggest that the mineralization of sulphides is associated to the late stage of $\mathrm{D}_{2}$ phase of deformation.

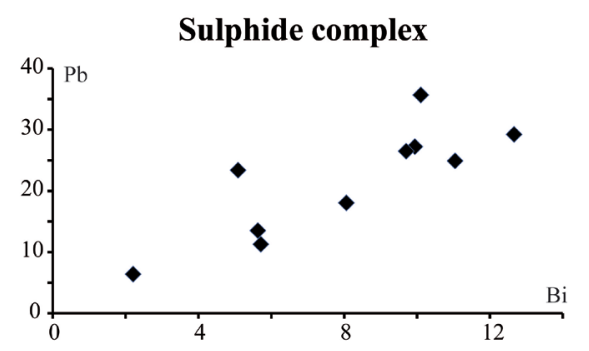

Figure 7. Binary diagram showing the correlation between Bismuth and $\mathrm{Pb}$ in complex sulphides (BiPbS). 


\subsection{Origin of Fluids and Mineralization Processes}

Syenite, which is the intrusive massif in orthogneissic basement, is an under-saturated rock, therefore low in silica. It is necessary to question the origin of the quartz and quartz-feldspar veins more or less mineralized in this massif. The search for the sources of the elements is one of the most difficult problems of metallogeny. It is now understood that the source of the vector that transports the elements can be independent of the source of the elements [21]. In addition to geochemical and isotopic data in particular, petrographic studies of the veins show hydrothermal phenomena marked by chloritization, sericitization, hematization and pyritization. It is therefore possible that hydrothermalism is one of the processes at the origin of mineralizing fluids. These fluids can be magmatic or metamorphic and come from the syenite pluton or surrounding rocks. They play a major role in the diffusion and recrystallization processes under pressure, particularly during metamorphism [22]. The mineralized veins south of Guider are deformed and show mineral transformations at the origin of the metal concentrations. The deformed and recrystallized nature of quartz crystals and the presence of $\mathrm{C} / \mathrm{S}$ planes in these rocks are indicative of the role of shear corridors. The syenite pluton which is a probable thermal source and the presence of many fracture planes blocked or not by veins suggest that the mode of circulation of mineralizing fluids south of Guider is forced convection (Figure 8). According to [23], forced convection, carried out around a warmer point (a pluton), corresponds to the repeated circulation (multiple pass) of the same fluids. Heavy cold fluids sink, heat up and become less heavy and rise. The density of the fluids is partially corrected due to the acquisition of dissolved elements at high temperature, which increases their density and therefore promotes their deposition. In this way, around the Guider syenite pluton there has been a forced convection whose size depends on the size of the pluton, its shape, its level of placement, its permeability and the distribution of permeability in the surrounding, in particular the existence of horizontal discontinuities.

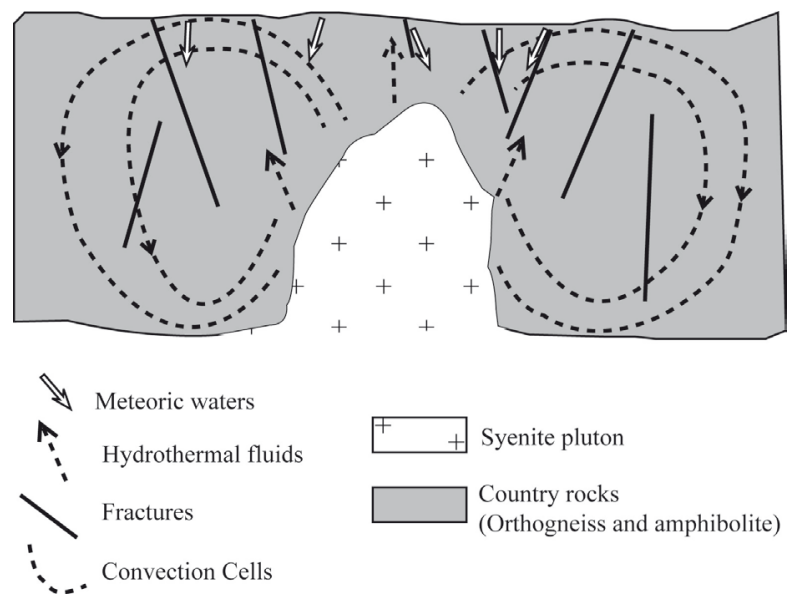

Figure 8. Diagram illustrating the role of guiding syenite and fractures in the mineralization of Guider's quartz and quartz-feldspar veins. 


\subsection{Quartz Generations and Mineralization}

The siliceous phase is the most important gangue of the ore bodies. Microscopic study of the mineralized veins revealed several generations of quartz associated with them (Figure 9). Quartz 1, with an S/C structure, was probably affected by a shear event that preceded its recrystallization into quartz 2 . The arrangement of the crystals constituting the latter in a chevron fold, whose axis is parallel to the $S_{2}$, is in favour of its crystallization during compression perpendicular to this planar structure compatible with the boudinage observed in the wall of some veins. Quartz 3 forms secant veinlets with quartz 1 and quartz 2. Quartz 2 is associated to chlorite \pm sericite \pm feldspar and sulphide represented pyrite, bismuthite and complex sulphides with $\mathrm{Bi}, \mathrm{Pb}, \mathrm{Ag}, \mathrm{Cu} \pm \mathrm{Au}$ and Fe. Like feldspar, quartz 1 is hematized compared to other group of quartz. The hematization of feldspar and quartz is a recognized process in the literature and so is its association with gold and sulphides mineralization [24] [25] [26] [27].

The study of the quartz and quartz-feldspar veins shows that pyrite and bismuthinite are the most abundant sulphides. Other metals such as $\mathrm{Cu}, \mathrm{Ag}, \mathrm{Pb}, \mathrm{Fe}$ and $\mathrm{Te}$ often combine with bismuth to form complex sulphides or sulphosalts that we have not been able to give an exact name.

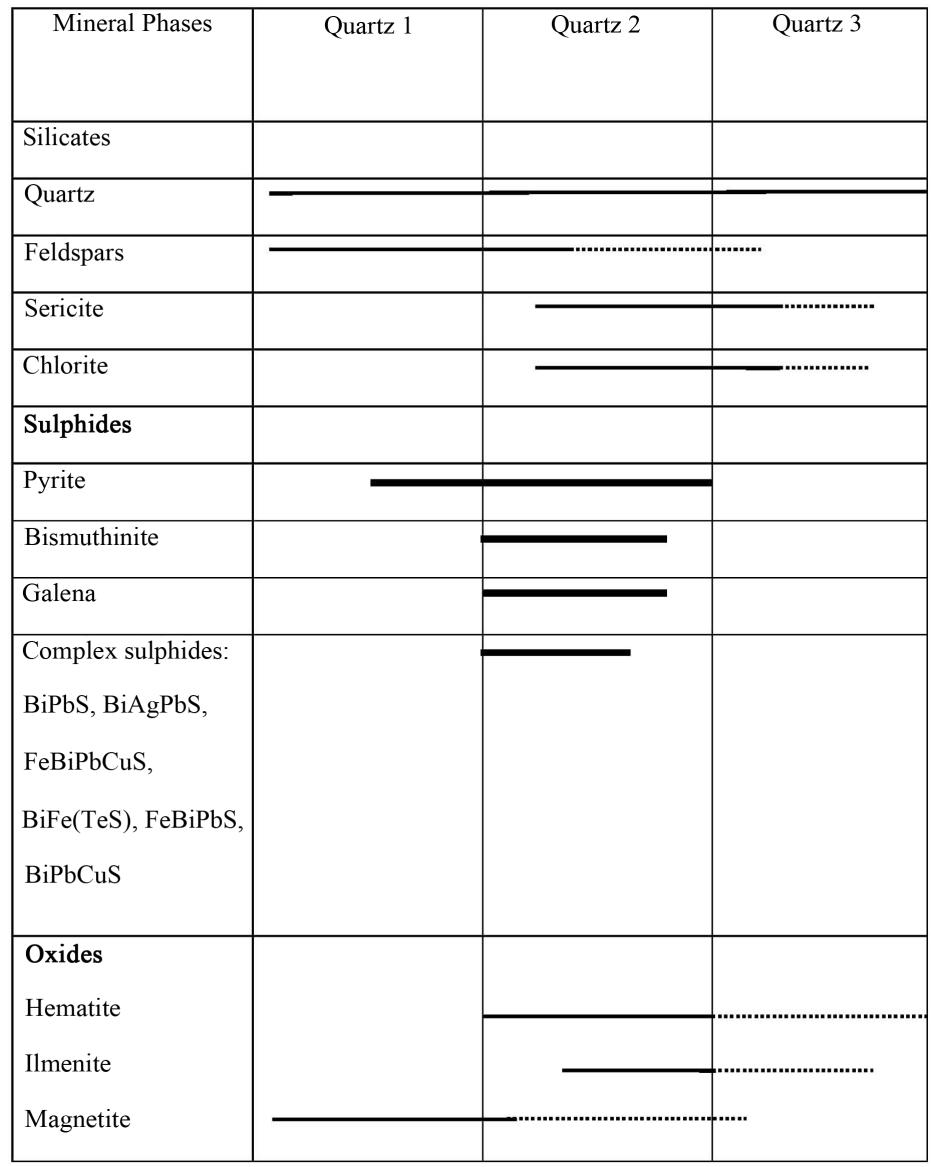

Figure 9. Mineralogical assemblages of mineralized veins in relation to primary (magmatic) quartz 1 and recrystallized quartz (quartz 2 and quartz 3). 
Pyrite, xenomorph to subautomorphic, large cracked beaches are always associated with quartz 1 or disseminated in surrounding rocks. Euhedral to subautomorphic pyrite seems to be mainly associated with recrystallization quartz (quartz 2 and shear quartz), with sometimes ambiguous relationships with quartz 1 . Bismuthinite sometimes present in quartz 2 contains other complex sulphides, oxides and pyrite inclusions. It therefore seems that the presence of sulphides ranges from the early phases of magmatism to the late phases of recrystallization and alteration of the veins and their hosts (syenite, gneiss and amphibolites). The magmatic source of the sulphides observed in these veins is therefore highly plausible. The more or less deformed magmatic rocks could have been subjected to repeated circulation of hydrothermal fluid, which may have remobilized the sulphides of the surrounding rocks to gradually and continuously enrich the veins. This mechanism can be considered for sulphide enrichment.

Oxides are represented by hematite with exsolutions of fibrous ilmenite and automorphic pyrite. This assembly indicates a reducing state of the hydrothermal fluid during crystallization or recrystallization of these oxides and sulphides [28]. However, these oxides may be of secondary supergenic origin [3]. It should also be noted that the relationships between sulphides, oxides, quartz types and host rock are not unambiguous and may be subject to discussion [29]. The textures of these sulphides and oxides appear to reflect remobilizations rather than crystallizations, resulting in the intersection of quartz grain boundaries, magmatic and tectonic structures. Sulphides have textures that can be interpreted in terms of their late emplacement relative to vein structure. Indeed, sulphides are essentially associated with quartz 2 or located at the C2 shear planes. Metamorphism coupled with tectonics played an important role in the mineralization of the Guider veins. However, further studies are needed to refine the genetic interpretation of mineralization.

From the petrographic and mineralogical studies, it appears that sulphides are associated with different generations of quartz and particularly with quartz 2 and quartz in shear zones. This can be interpreted in terms of the continuous and repeated remobilization of sulphides from its source (magmatic or hydrothermal) to feed the veins throughout their establishment and evolution. This explanation has also been proposed by [30] for gold from the Phanerozoic fold belt of Victoria in Australia and the late quartz veinlets, which intersect the latter, appear sterile.

\subsection{Metal Paragenesis and Species Chronology}

The mineralographic observations allow us to propose a metallic paragenesis, based mainly on the observed textural relationships. Paragenesis consists in interpreting the mineralogical evolution of the deposit [31]. In the veins studied, we note the existence of two morphological forms of quartz:

1) quartz, prior to early mineralization, is in the form of coarse grains and/or highly fractured crystals. Some fractures are filled with pyrite and/or hematite 
and magnetite relics. Also, between the coarse grains of this quartz, some pyrite grains are observed which are then porphyroblastic and relatively undeformed. These sulphides are therefore being filled (as is the case for those in fractures) following a precipitation slightly later than this quartz or following a redistribution caused by a deformation;

2) recrystallized quartz may be found in fractures or borders of the previous quartz. The sulphides present with this type of quartz are cataclased in places. The pyrite is formed, more locally, by a precipitation contemporary to this recrystallized quartz. Pyrite crystals are observed in contact with recrystallized quartz grains, suggesting that this sulphide is not later than recrystallized quartz, but rather contemporary to it. Gangue minerals, such as chlorite, hematite and sericite, are found in these deformed zones of mineralization, where recrystallized quartz is more abundant. It is likely that the cooling fractures of Guider's syenite [13] were initially filled with quartz with pyrites, ilmenite and magnetite. This primary mineralization by filling was resumed by a subsequent deformation that produced the cataclase of quartz and primary sulphides (pyrite). The subsequent intense cataclase suffered by these veins and veinlets would have caused neomineralization and formation of small quartz grains and created openings allowing the placement and/or redistribution of sulphides, certain gangue minerals, and possibly locally, a new injection of sterile or mineralized quartz in late pyrite, bismuthinite and other sulphides with $\mathrm{Bi}, \mathrm{Ag}, \mathrm{Cu}, \mathrm{Pb}$. The sulphides present in the veins, veins and veintles were probably formed largely by a reaction between the fluids and the fragments of the host or the host itself on contact. Sulphides are very frequently directly attached to the altered syenite.

According to petrographic observations, most of the metal phases began to precipitate simultaneously. However, since pyrite contains inclusions of almost all other metal phases, it seems to have continued to develop after the formation of the other metal phases it has incorporated as well as some gangue crystals. Since most mineralized veins are close to the syenite pluton, there appears to be a spatial and genetic link between the presence of the host syenite and the presence of sulphides. The order of crystallization of the phases is shown in

Micas are characterized by a correlative substitution between $\mathrm{Si}^{\mathrm{IV}}$ and $\mathrm{Al}^{\mathrm{IV}}$ and between $\mathrm{Fe}^{2+}$ and $\mathrm{Al}^{(\mathrm{VI})}$ (Figures not shown). However, there is no substitution between $\mathrm{Fe}^{2+}$ and $\mathrm{Si}^{4+}$. According to [32] the substitution of $\mathrm{Al}^{\mathrm{IV}}$ with $\mathrm{Si}^{\mathrm{IV}}$ is temperature-dependent and varies between $230^{\circ} \mathrm{C}$ and $275^{\circ} \mathrm{C}$, in the silicified and sericitized zone. They determined a temperature ranging from $250^{\circ} \mathrm{C}$ to $310^{\circ} \mathrm{C}$ in the chlorite zone at the Home Mine (Noranda, Quebec). These same types of substitutions and alterations are also found at the Tiouit Mine in anti-atlas oriental (south of Morocco) [33]). So, the same range of alteration temperatures and associated mineralization can be considered for Guider mineralized veins.

\subsection{Critical View on the Typology of Mineralization}

The association of mineralized quartz veins with shear zones suggests that the 
Guider mineralization is of the mesothermal type [34]. Near-surface intrusions provide favourable sites for the formation and development of mineralization with characteristics ranging from epithermal to sulphides and copper porphyry [35].

The majority of porphyry deposits have the same overall evolutionary history, although they may differ in detail. Guider mineralized veins display some of the known characteristics of copper-bearing porphyry calc-alkali veins, but they differ from them by their considerably widespread and highly impregnated alteration and overall hematite richness. This abundance of hematite is a particularity of Guider's mineralized veins. Hematite is the most distinctive alteration product in these veins. This probably intermittent hematization from different sources distinguishes this deposit from the usual copper porphyries [36]. According to some authors [37] [38], considerable quantities of Fe can be extracted from an acidic to intermediate magma. Rocks that are in contact with a retrograde boiling of brine-laden fluids are capable of releasing appreciable amounts of iron [39]. Also, under conditions of low $\mathrm{pH}$, an oxidizing medium and temperatures $<360^{\circ} \mathrm{C}$, magnetite transforms into hematite, with a sericite-clay-chlorite alteration assemblage. These conditions also favour the concentration of Au and sulphides [39] [40] [41]. The appreciable quantity of hematite in Guider's mineralized veins is probably produced, among other things, by the martitization of hypogenous hydrothermal magnetite or, incidentally, magmatic magnetite. The latter mineral and part of the hematite are locally transformed into pyrite. By way of comparison, the abundance of iron in the Marte mine (northern Chile) [36], is mainly represented by magnetite that has not been martitized as in the case of Guider.

Our results show that some aspects of alteration (serialization, chloritization, pyritization, silicification, and oxidation) that characterize porphyry-Cu deposits [42] do exist around the calc-alkali Guider pluton. However, their distribution is less regular and relatively more complex than that corresponding to the classical zonation described by the authors who have worked on Cu-porphyres [35] [41] [43]. The majority of the studies of these authors concern recent deposits where, zonation of alterations and associated mineralization are not affected by subsequent episodes (metamorphism, deformation, erosion). On the other hand, older deposits (such as the Pan-African Guider pluton) are probably affected, changed or displaced, so their recognition and classification become relatively problematic. A more detailed isotope-based study is needed to refine the nature, origin of the fluids and the classification of Guider's sulphide mineralization.

\section{Conclusions}

This work focused on the metallogenesis of sulphide mineralization of Guider quartz and quartz-feldspar veins within the syenitic pluton of Guider. The purpose of studying these veins was to calibrate their generation in relation to the different deformation phases and to characterize the associated mineralization. 
At the centre of the pluton, they outcrop as veins, pockets or metric to decametric veins crosscutting the syenitic massif. In addition to quartz and feldspar, these veins are composed of alteration and recrystallization products (chlorite, sericite, quartz, hematite), sulphides and iron oxides.

Pyrite and bismuthinite are the most abundant sulphides. Other metals such as $\mathrm{Cu}, \mathrm{Ag}, \mathrm{Pb}, \mathrm{Fe} \pm \mathrm{Au}$ and $\mathrm{Te}$ often combine with bismuth to form complex sulphides. Sulphides are associated with quartz 1 and quartz in shear zones. This can be interpreted in terms of continuous and repeated remobilization of its source (magmatic or hydrothermal) to feed the veins throughout their establishment and evolution.

Petrographic studies of the veins show hydrothermal phenomena marked by chloritization, sericitization, hematization and pyritization. It is therefore possible that hydrothermalism is one of the processes at the origin of mineralizing fluids. These fluids can be magmatic or metamorphic and come from the syenite pluton or surrounding rocks (orthogneiss and amphibolite).

The results obtained by this study show that some alteration aspects (chloritization, hematization, pyritization, sericitization) that characterize porphyry-Cu deposits do exist around the Guider pluton. However, their distribution is less regular and relatively more complex than that corresponding to the classical zonation described by the authors who worked on the $\mathrm{Cu}$ porphyres.

\section{Acknowledgements}

This article is part of Boyabe Marguerite's Ph.D thesis. The mineralogical analyses were financed by the Labex Resources 21 project (Project No. ANR-10-LABX-21-01). The authors would like to thank Pr Sylvie-André Mayer for his collaboration, Olivier Rouer, for his assistance during the electron microprobe analyses, and Alexandre Flannory for the production of thin sections, at the Georessources laboratory, Universite de Lorraine, Nancy (France). The authors thank Mr Mbainadjim Mbette who accepts to perform the English of the first version of manuscript.

\section{Conflicts of Interest}

The authors declare no conflicts of interest regarding the publication of this paper.

\section{References}

[1] Cox, S.F. (1987) Flow Mechanisms, in Sulphide Minerals. Ore Geology Review, 2, 133-171. https://doi.org/10.1016/0169-1368(87)90026-6

[2] Gerdes, M.L., Baumgartner, L.P. and Person, M. (1998) Convective Fluid Flow through Heterogeneous Country Rocks during Contact Metamorphism. Journal of Geophysical Research: Solid Earth, 103, 23983-24003. https://doi.org/10.1029/98JB02049

[3] Goldfarb, R.J., Groves, D.I. and Gardoll, S. (2001) Orogenic Gold and Geologic Time: A Global Synthesis. Ore Geology Reviews, 18, 1. 
https://doi.org/10.1016/S0169-1368(01)00016-6

[4] Thompson, J.H.F. and Newberry, R.J. (2000) Gold Deposits Related to Reduced Granitic Intrusions. Reviews in Economic Geology, 13, 377-400.

https://doi.org/10.5382/Rev.13.11

[5] Lang, J.R. and Baker, T. (2001) Intrusion-Related Gold Systems: The Present Level of Understanding. Mineralium Deposita, 36, 477-489. https://doi.org/10.1007/s001260100184

[6] Schwoerer, P. (1965) Notice explicative sur la feuille Garoua Est avec carte géologique de reconnaissance au 1/500000. Direction des mines et géologie, Imprimerie Nationale Yaoundé, Yaoundé, 49 p.

[7] Thoste, V. (1985) Mineral Exploration in North Cameroon, Region of Poli. Final Report, Federal Republic of Germany, Number of Project 80.2273.3.

[8] Pinna, P., Edimo, A., Jézéquel, J., Tchounthoui, D. and Ebotayuk-Ebop, M. (1989) Inventaireminier du Centre Nord-Cameroun, (troisième phase) open-file Report 86 CMR168. Bureau de Recherches Géologiques et Minières, France.

[9] Njel, U.O. (1986) Paléogéographie d'un Segment de l'Orogenèse Panafricaine, la Ceinture Volcano-Sédimentaire de Poli (Nord Cameroun). Compte Rendu de PAcadémie des Sciences, 30, 1737-1742.

[10] Kouské, A.P., Suh, C.E., Ghogomu, R.T. and Ngako, V. (2012) Na-Metasomatism and Uranium Mineralization during a Two-Stage Albitization at Kitongo, Northern Cameroon: Structural and Geochemical Evidence. International Journal of Geosciences, 3, 258-279. https://doi.org/10.4236/ijg.2012.31028

[11] Fosso Tchunte, P.M., Tchameni, R., André-Mayer, A.S., Dakoure, H., Turlin, F., Poujol, M., Nomo, E., Saha Fouetsa, N.A. and Rouer, O. (2018) Evidence for Nb-Ta Occurrences in the Syn-Tectonic Pan-African Mayo Salah Leucogranite (Northern Cameroon): Constraints from Nb-Ta Oxide Mineralogy, Geochemistry and $\mathrm{U}-\mathrm{Pb}$ LA-ICP-MS Geochronology on Columbite and Monazite. Minerals, 8, 10. https://doi.org/10.3390/min8050188

[12] Dawaï, D. (2014) Les plutons de Guider et de Bossoum-Pologozom (chaîne panafricaine au Nord Cameroun): Analyse pétrographique, structurale, magnétique, géochronologique et implications géodynamiques. Doctorat de l'Université de Toulouse/Doctorat/PhD Université de Ngaoundéré, 208 p.

[13] Dawaï, D., Bouchez, J.L., Paquette, J.L. and Tchameni, R. (2013) The Pan-African Quartz-Syenite of Guider (North-Cameroon): Magnetic Fabric and U-Pb Dating of a Late-Orogenic Emplacement. Precambrian Research, 236, 132-144.

https://doi.org/10.1016/j.precamres.2013.07.008

[14] Toteu, F.S., Penaye, J. and Poudjoun Djomani, Y. (2004) Geodynamic Evolution of Pan-African Belt in Central Africa with Special Reference to Cameroon. Journal African Earth Sciences, 41, 73-85. https://doi.org/10.1139/e03-079

[15] Ngako, V., Affaton, P. and Njonfang, E. (2008) Pan-African Tectonics in Northwestern Cameroon: Implication for the History of Western Gondwana. Gondwana Research, 14, 509-522. https://doi.org/10.1016/j.gr.2008.02.002

[16] Van Schmus, W.R., Oliveira, E.P., Da Silva Filho, A.F., Toteu, S.F., Penaye, J. and Guimarães, I.P. (2008) Proterozoic Links between the Borborema Province, NE Brazil, and the Central African Fold Belt. In: Pankhurst, R.J., Trouw, R.A.J., de Brito Neves, B.B. and De Wit, M.J., Eds., West Gondwana. Pre-Cenozoic Correlations across the South Atlantic Region, 294, Geological Society, London, 69-99.

https://doi.org/10.1144/SP294.5 
[17] Toteu, S.F., Penaye, J., Deloule, E., Van Schmus, W.R. and Tchameni, R. (2006) Diachronous Evolution of Volcano-Sedimentary Basins North of the Congo Craton: Insights from U-Pb Ion Microprobe Dating of Zircons from the Poli, Lom and Yaounde Series (Cameroon). Journal of African Earth Sciences, 44, 428-442. https://doi.org/10.1016/j.jafrearsci.2005.11.011

[18] Toteu, S.F. (1990) Geochemical Characterization of the Main Petrographical and Structural Units of Northern Cameroon: Implications for Pan-African Evolution. Journal of African Earth Sciences, 10, 615-624. https://doi.org/10.1016/0899-5362(90)90028-D

[19] Zane, A. and Weiss, Z. (1998) A Procedure for Classifying Rock-Forming Chlorites Based on Microprobe Data. Rendiconti Lincei, 9, 51-56.

https://doi.org/10.1007/BF02904455

Foster, M.D. (1962) Interpretation of the Composition and a Classification of the Chlorites. Prof. Pap. US Geological Survey, 414A, 1-33.

[20] Miller, C.F., Stoddard, E.E., Bradfish, L.J. and Dollase, W.A. (1981) Composition of Plutonic Muscovite: Genetic Implications. Canadian Mineralogist, 19, 25-34.

[21] Zheng, Z., Deng, X.H., Chen, H.J., Yue, S.W., Dong, L.H., Qu, X. and Chen, Y.J. (2016) Fluid Sources and Metallogenesis in the Baiganhu W-Sn Deposit, East Kunlun, NW China: Insights from Chemical and Boron Isotopic Compositions of Tourmaline. Ore Geology Reviews, 72, 1129-1142. https://doi.org/10.1016/j.oregeorev.2015.09.006

[22] Touret, J.L.R. (2001) Fluid in Metamorphic Rocks. Lithos, 55, 1-25. https://doi.org/10.1016/S0024-4937(00)00036-0

[23] Elder, J.W. (1981) Geothermal Systems. Academic, Troy, 508 p.

[24] Moorhouse, W.W. (1959) The Study of Rocks in Thin Section. Harper and Row, New York, 514 p.

[25] Hofmeister, A.M. and Rossman, G.R. (1983) Color in Feldspars. In: Ribbe, P.H., Ed., Feldpsar Mineralogy, 2nd Edition, Reviews in Mineralogy No. 2, Mineralogical Society of America, Washington DC, 271-280. https://doi.org/10.1515/9781501508547-016

[26] Craw, D., Windle, S.J. and Angus, P.V. (1999) Gold Mineralization without Quartz Veins in a Ductile-Brittle Shear Zone, Macraes Mine, Otago Schist, New Zealand. Mineralum Deposita, 34, 382-394. https://doi.org/10.1007/s001260050211

[27] Dubé, B., Gosselin, P., Mercier-Langevin, P., Hannington, M. and Galley, A. (2007) Gold-Rich Volcanogenic Massive Sulphide Deposits. In: Goodfellow, W.D., Ed., Mineral Deposits of Canada: A Synthesis of Major Deposit-Types, Disctict Metallogeny, the Evolution of Geological Provinces, and Exploration Methods, Geological Association of Canada, Mineral Deposits Division, Special Publication 5, 75-94.

[28] Kesler, S.E., Riciputi, L.C. and Ye, Z. (2005) Evidence for a Magmatic Origin for Carlin-Type Gold Deposits: Isotopic Composition of Sulfur in the Betze-Post Screamer Deposit, Nevada, USA. Mineralium Deposita, 40, 127-136. https://doi.org/10.1007/s00126-005-0477-9

[29] Hedenquist, J.W. and Lowenstern, J.B. (1994) The Role of Magmas in the Formation of Hydrothermal Ore Deposits. Nature, 370, 519-552. https://doi.org/10.1038/370519a0

[30] Bierlein, F.P. and Maher, S. (2001) Orogenic Disseminated Gold in Phanerozoic Fold Belts Examples from Victoria, Australia and Elsewhere. Ore Geology Reviews, 18, 113-148. https://doi.org/10.1016/S0169-1368(01)00019-1 
[31] Titley, S.R. (1994) Evolutionary Habits of Hydrothermal and Supergene Alteration in Intrusion-Centred Ore Systems, Southwestern North America. In: Lentz, D.R., Éd., Alteration and Alteration Processus Association with Ore-Forming Systems, Geological Association of Canada, St. John's, Short Course Notes No. 11, 237-259.

[32] MacLean, W.H. and Lawrence, D.H. (1991) Geochemistry of Hydrothermally Altered Rocks at the Home Mine, Noranda, Quebec. Economic Geology, 86, 506-528. https://doi.org/10.2113/gsecongeo.86.3.506

[33] Chaker, M. (1997) Géochimie et métallogénie de la mine d'or de Tiouit, anti-atlas oriental sud du Maroc. Thèse présentée à l'Université du Québec à chicoutimi. https://doi.org/10.1522/1531540

[34] Windh, J. (1995) Saddle Reef and Related Gold Mineralization, Hill End Gold Field, Australia: Evolution of an Auriferous Vein System during Progressive Deformation. Economic Geology, 90, 1764-1775. https://doi.org/10.2113/gsecongeo.90.6.1764

[35] Sillitoe, R.H. (2010) Porphyry Copper Systems. Economic Geology, 105, 3-41. https://doi.org/10.2113/gsecongeo.105.1.3

[36] Vila, T. and Sillitoe, R.H. (1991) Gold-Rich Porphyry Systems in the Mari-Cunga Belt, Northern Chile. Economic Geology, 86, 1238-1260. https://doi.org/10.2113/gsecongeo.86.6.1238

[37] Kilinc, I.A. (1969) Composition of Melts Formed from Partial Melting of Shales and Graywackes. Geological Society of America, Annual Meeting, 125 Abstracts, Boulder.

[38] Whitney, A. and Stormer Jr., C. (1985) Mineralogy, Petrology, and Magmatic Conditions from the Fish Canyon Tuff, Central San Juan Volcanic Field, Colorado. Journal of Petrology, 26, 726-762. https://doi.org/10.1093/petrology/26.3.726

[39] Arancibia, O.N. and Clark, A.H. (1996) Early Magnetite-Amphibole-Plagioclase Alteration-Mineralization in the Island Copper Porphyry Copper-Gold Molybdenum Deposit, British Columbia. Economic Geology, 91, 402-438. https://doi.org/10.2113/gsecongeo.91.2.402

[40] Pettke, T., Oberli, F. and Heinrich, C.A. (2010) The Magma and Metal Source of Giant Porphyry-Type Ore Deposits, Based on Lead Isotope Microanalysis of Individual Fluid Inclusions. Earth Planetary Science Letter, 296, 267-277. https://doi.org/10.1016/j.epsl.2010.05.007

[41] Sun, W., Huang, R., Li, H., Hu, Y., Zhang, C., Sun, S., Zhang, L., Ding, X., Li, C., Zartman, R.E. and Ling, M. (2015) Porphyry Deposits and Oxidized Magmas. Ore Geological Reviews, 65, 97-131. https://doi.org/10.1016/j.oregeorev.2014.09.004

[42] Selby, D., Nesbitt, B.E., Muehlenbachs, K. and Prochaska, W. (2000) Hydrothermal Alteration and Fluid Chemistry of the Endako Porphyry Molybdenum Deposit, British Columbia. Economic Geology, 95, 183-202. https://doi.org/10.2113/gsecongeo.95.1.183

[43] Beane, R.E. and Titley, S.R. (1981) Porphyry Copper Deposits. Part II. Hydrothermal Alteration and Mineralization. Economic Geology 75th Anniversary, 235-269. 